\title{
硫酸ニッケル水溶液中でのアルミニウム陽極酸化皮膜 のカソード分極特性に及ぼす電解質の影響
}

\author{
佐 藤 敏 彦* ・酒 井茂* \\ Effects of Electrolytes on Cathodic Polarization Curves of \\ Aluminum Oxide Films in a Nickel Sulfate Solution
}

Toshihiko SATO* and Shigeru SAKAI*

\begin{abstract}
Anodic oxide films on aluminum formed in a sulfuric acid bath are cathodically polarized in a mixed solution of nickel sulfate with boric acid by the potential sweep method. Three peaks of cathodic current are observed on the voltammograms. The peak current at $-4(\mathrm{~V})$ is due to reduction of $\mathrm{H}^{+}$ions, and the cause of the peak current at $-13(\mathrm{~V})$ is unknown. The peak current at $-18(\mathrm{~V})$ is due to reduction of $\mathrm{Ni}^{2+}$ ions.
\end{abstract}

\section{1. 緒}

アルミニウム陽極酸化皮膜を金属塩水溶液中でカソー ド分極すると，アルミニウム陽極酸化皮膜がかっ色ない し黒色に着色される。この現象はアルミニウム表面処理 技術に拈いて，“直流電解着色法”として国内外で工業 化されている1)。しかし, 直流電解着色法の基礎研究は 少なく，広兼らによる報文が発表されているたけであ

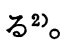

本報では硫酸ニッケルーホウ酸混合水溶液中でのアル ミニウム陽極酸化皮膜のカソード分極特性及び分極特性 に対する電解質の影響について報告する。な拉，厚い多 孔質酸化皮膜で覆われたアルミニウム電極を金属塩水溶 液中でカソード分極する実験に対して，金属/水溶液系 の電極反応論的アプローチをすることには多くの問題が

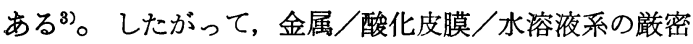
な電極反応論を展開することは本研究の目的ではない。 本研究は，あくまでも，アルミニウム直流電解着色法の 基礎研究として行なった実験である。

\section{2. 実験試料及び方法}

アルミニウム試料は純度 $99.5 \% \mathrm{Al}$ のアミニウム板 $(2 \times 5 \times 0.03 \mathrm{~cm})$ を用いた。アルミニウム陽極酸化皮膜 は15wt.\% $\mathrm{H}_{2} \mathrm{SO}_{4}$ 水溶液（液温 $20^{\circ} \mathrm{C}$ ） 中で直流電圧15 Vにて定電圧化成により作成した。いずれの陽極酸化皮 膜も皮膜厚さを $9 \mu \mathrm{m}$ 一定とした。

硫酸ニッケル水溶液中でのアルミニウム陽極酸化皮膜

*芝浦工業大学 (干108 港区芝浦3-9-14)

Shibaura Institute of Technology 3-9-14, Shibaura, Minato-ku, Tokyo 108
のカソード分極は図 1 に示す装置により行なった。直流 電源は高砂製作所製直流安定化電源装置 (GP 0110-1型) を使用した。直流電圧のリップルは $110 \mathrm{~V}$ 出力電圧のと き $5 \mathrm{mV}$ 以下であった。電位走査器は筆者らの研究室で試 作した装置を用いた。 $10 \mathrm{sec} / \mathrm{V}$ を標準電位走查速度とし た。電解電流は図 1 に示してある固定抵抗, $\mathrm{R}_{0}(1.0 \Omega)$ による電圧降下として検出した。 $\mathrm{R}_{0}$ による電圧降下が 印加電圧に与える影響は $0.1 \mathrm{~V}$ 以下であった。アルミニ ウム陽極酸化皮膜で覆われている作用電極の電極電位は $100 \mathrm{~cm}^{2}$ の白金対極と作用電極の 両端の浴電圧で代用し た。浴電圧を作用電極の電極電位とみなしても, その差 異は0.5V以下であった。本実験では，カソード部分の 電位降下がー20Vにも及ぶので浴電圧をそのままカソー ド電位とみなしても実験結果に重大な影響を与兄ない。

アルミニウム陽極酸化皮膜のカソード分極は $30 \mathrm{~g} / \mathrm{l}$ $\mathrm{NiSO}_{4} \cdot 6 \mathrm{H}_{2} \mathrm{O}-30 \mathrm{~g} / l \mathrm{H}_{3} \mathrm{BO}_{3}$ 混合水溶液 (浴温 $25^{\circ} \mathrm{C}$ ) を 標準電解液として行なった。な拉，本実験において使用 した化学薬品はいずれも特級試薬である。一部の実験以 外は電解液中の溶存酸素除去を行なわずに実験した。

\section{3. 実験結果及び考察}

図 2 は硫酸浴で化成した $9 \mu \mathrm{m}$ のアルミニウム陽極酸 化皮膜を $30 \mathrm{~g} / l \mathrm{NiSO}_{4} \cdot 6 \mathrm{H}_{2} \mathrm{O}-30 \mathrm{~g} / l \mathrm{H}_{3} \mathrm{BO}_{3}$ 混合水溶液 中でカソード分極した時の分極曲線を示す。 $-4 \mathrm{~V},-13$ V及びー18Vに3つのカソード電流ピークが認められ る。以下の文章に拈いて， $-4 \mathrm{~V}$ の電流ピークを第 1 ピ 一ク，一13V及びー18Vの電流ピークを，それぞれ第 2 ピーク及び第 3 ピークと呼ぶことにする。電気めっきな どの金属/水溶液系のカソード分極曲線に比べて, 図 2 のカソード過電圧が著しく大きい。この原因は, 作用電 
極上のアルミニウム陽極酸化皮膜による抵抗過電圧のた めである。

吉田らは硫酸ニッケル水溶液中で白金電極をカソード 分極すると一0.5V(vs. SCE) 飞水素イオンの還元電流, $-0.8 \mathrm{~V}$ (vs. SCE)にニッケル・イオンの還元電流, -1.0 $\mathrm{V}$ (vs. SCE) に水の直接還元 $\left(2 \mathrm{H}_{2} \mathrm{O}+2 \mathrm{e} \rightarrow \mathrm{H}_{2}+2 \mathrm{OH}^{-}\right)$ による還元電流が現われることを報告している 吉田らの実験に打いては電解液中の溶存酸素を除去して いる。吉田らの研究結果も参照しながら, 図 2 のカンー ド電流ピークの帰属を検討していく。

図 3 流酸ニッケルーホウ酸混合水溶液に硫酸を添加 して，電解液の $\mathrm{pH}$ を変化させた時のアルミニウム陽極 酸化皮膜の分極曲線を示す。 $\mathrm{pH} 2.4$.の時のボルタングラ ムは硫酸を添加していない硫酸ニッケルーホウ酸混合水 溶液 (pH 3.6) の時のボルタングラムとほとんど同じで ある。しかし， pH2.0になると，一-3Vで電流が急激に 流れはじめて単調増加する。このことより，図2のボル タングラムに括惊第 1 電流ピークは水素イオンの還元 電流である。

第 2 電流ピークの帰属を決定するために 2,3 の実験

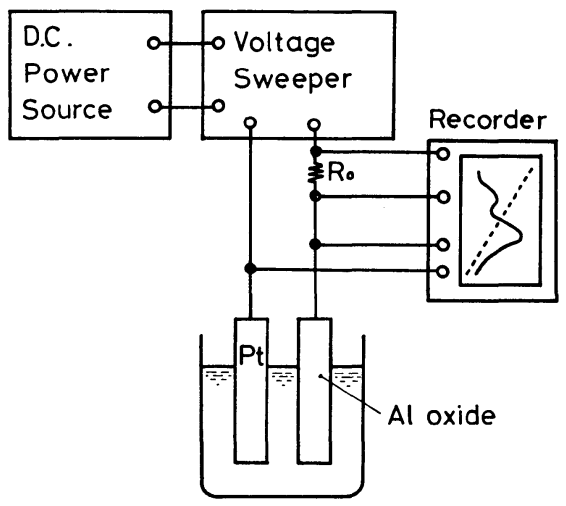

Fig. 1 Measurement of voltammogram by control of cell voltage.

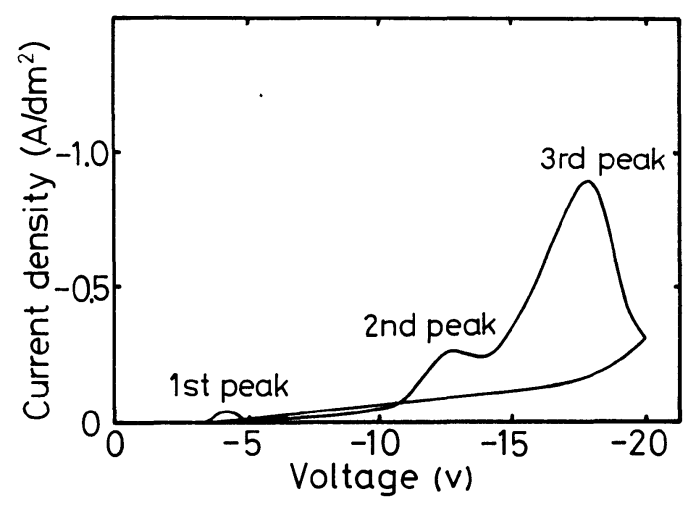

Fig. 2 Cathodic polarization curves of oxide film in $\mathrm{NiSO}_{4}-\mathrm{H}_{3} \mathrm{BO}_{3}$ solution-Standard curve.
を行なったが，結論は得られなかった。開放系電解セル に窒素ガスを吹き込んでカソード分極実験を行なったが 第 2 電流ピークは数\%程度減少したにすぎなかった。図 4は硫酸ニッケルーホウ酸混合水溶液に 過酸化水素を添 加した時のアルミニウム陽極酸化皮膜のカソード分極曲 線を示す。過酸化水素の添加量が増加すると，第 2 電流

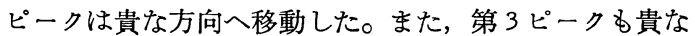
方向へ移動し，その電流值は著しく減少した。な技，過 酸化水素の添加により第 3 ピークの電流が減少したの は, 過酸化水素の還元によって生成された $\mathrm{OH}^{-}$のため にニッケル・イオンの電析（後述）が妨害されたためで ある。硫酸ニッケルーホウ酸混合水溶液の 過酸化水素濃 度が増加すると，アルミニウム陽極酸化皮膜は着色され にくくなり，かわりに水酸化ニッケルと思われる緑色の 付着物が現われた。ここで, 第 2 電流ピークの帰属を溶 存酸素の還元反応 $\left(\frac{1}{2} \mathrm{O}_{2}+\mathrm{H}_{2} \mathrm{O}+2 \mathrm{e} \rightarrow 2 \mathrm{OH}^{-}\right)$であると仮 定すると以下の 2 点が問題になる。

（1）一般の電極反応に拈いては $\mathrm{H}^{+}$の還元よりも貴な 電位で溶存酸素の還元が起る。

（2）一般に水溶液中の溶存酸素の濃度は常温で $1 \times$ $10^{-4} \sim 2 \times 10^{-4} \mathrm{~mol} / l$ と, 極めて低く, この溶存酸

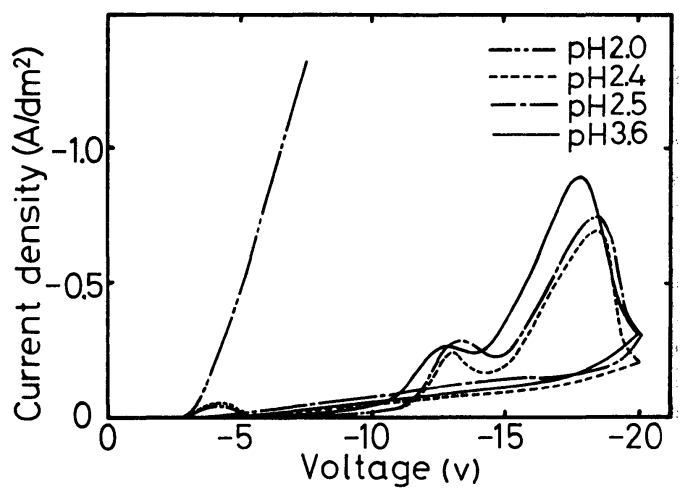

Fig. 3 Cathodic polarization curves of oxide film in $\mathrm{NiSO}_{4}-\mathrm{H}_{3} \mathrm{BO}_{3}$ solution.-Effects of $\mathrm{pH}$.

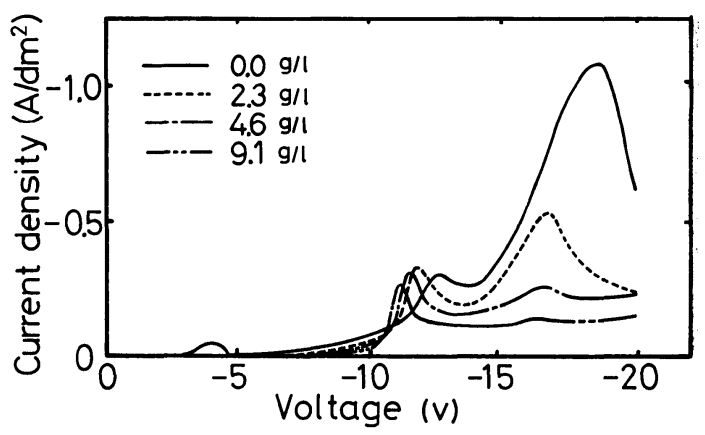

Fig. 4 Cathodic polarization curves of oxide film in $\mathrm{NiSO}_{4}-\mathrm{H}_{3} \mathrm{BO}_{3}$ solution.-Effects of $\mathrm{H}_{2} \mathrm{O}_{2}$. addition. 
素の還元拡散限界電流密度は $1 \times 10^{-3} \mathrm{~A} / \mathrm{dm}^{2}$ のオー ダーであることが知られている。第 2 電流ピークの 值はこの值よりはるかに大きい。

したがって, 現時点で第 2 電流ピークの帰属は不明で あるが，今後の問題としてアルミニウム陽極酸化皮膜自 身のカソード還元の可能性を検討する必要があるだろ う。

図 5 は硫酸ニッケルーホウ酸混合水溶液への硫酸ナト リウム添加の影響を示す。硫酸ナトリウム濃度が $10 \mathrm{mg} / \mathrm{l}$ と $20 \mathrm{mg} / l$ になると, 第 3 ピークは消滅する。また, これ らの浴に执いてはアルミニウム陽極酸化皮膜は着色され なかった。アルミニウム陽極酸化皮膜の直流電解着色法 に扣いては，電解着色浴中に $10 \mathrm{ppm}$ 程度のナトリウム ・イオンが共存すると, アルミニウム陽極酸化皮膜が着 色されなくなることが工業的にも知られている22。この

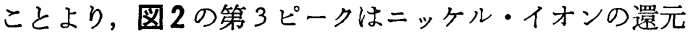
電流である。な㧧, 硫酸ナトリウム添加により第 2 ピー クの電流は增加している。

硫酸ニッケルーホウ酸混合水溶液のホウ酸濃度を一定 $(30 \mathrm{~g} / l)$ にして，硫酸ニッケルの濃度を $10 \mathrm{~g} / l$ から $210 \mathrm{~g} / l$ まで変化させた。図 6 はアルミニウム陽極酸化皮膜の力 ソード分極特性に及ぼす硫酸ニッケル濃度の影響を示 す。硫酸ニッケル $10 \mathrm{~g} / l$ の時はー3V 付近からカソード電 流は単調に増加し，アルミニウム陽極酸化皮膜は着色さ れなかった。硫酸ニッケル濃度が $30 \mathrm{~g} / l$ の時と $50 \mathrm{~g} / \mathrm{l}$ の 時はボルタングラムが注とんど同一であった。 $90 \mathrm{~g} / l$ 以 上の硫酸ニッケル濃度の時は硫酸ニッケル濃度の増加に

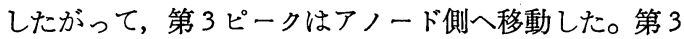
ピークの電流值は $150 \mathrm{~g} / l \mathrm{NiSO}_{4} \cdot 6 \mathrm{H}_{2} \mathrm{O}$ の時に最大であっ た。硫酸ニッケル濃度の変化による第 2 ピークの変化は 小さかった。図6のデータからも第3ピークはニッケル ・イオンの還元電流であることがわかる。な拉，图6の 実験に拈いては硫酸根アニオンのイオン強度を一定にす

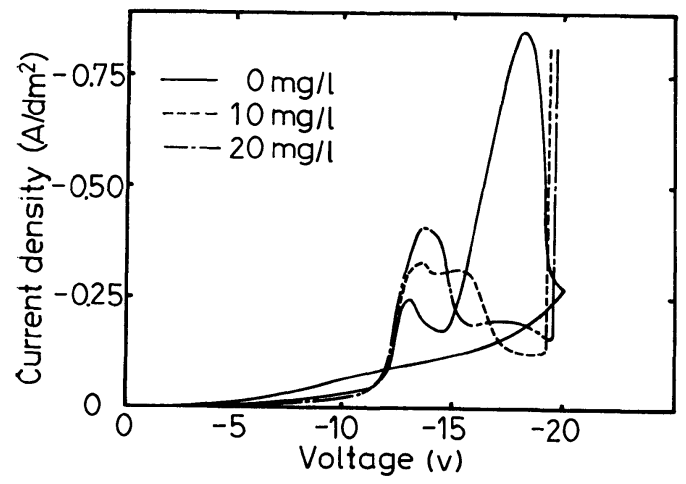

Fig. 5 Cathodic polarization curves of oxide film in $\mathrm{NiSO}_{4}-\mathrm{H}_{3} \mathrm{BO}_{3}$ solution.-Effects of $\mathrm{Na}_{2} \mathrm{SO}_{4}$ addition
べきであったが，適当な無関係電解質を見いだすことが できなかった。例えば， $30 \mathrm{~g} / l$ 硫酸ニッケルー30g/l ホウ 酸混合水溶液に硫酸アンモニウムを添加すると，アルミ ニウム陽極酸化皮膜の分極曲線は図 7 のように変化し た。硫酸アンモニウム添加量が増加すると着色皮膜の色 の濃さが淡くなり, 硫酸アンモニウムが $3.77 \mathrm{~g} / l$ 以上の 時は着色しなくなる。

图 8 は $30 \mathrm{~g} / l \mathrm{NiSO}_{4} \cdot 6 \mathrm{H}_{2} \mathrm{O}-30 \mathrm{~g} / l \mathrm{H}_{3} \mathrm{BO}_{3}$ 混合水溶液中 でのアルミニウム陽極酸化皮膜のカソード分極に拈ける 電位走查速度の影響を示す。走查速度の増加に上り, 第 3 ピークは卑な方向に移動していく。このことより，ア ルミニウム陽極酸化皮膜中へのニッケル・イオンの電析 反応は非可逆性が大きいといえる。

図 9はホウ酸濃度の影響を示す。硫酸ニッケル濃度は $30 \mathrm{~g} / \mathrm{l} \mathrm{NiSO}_{4} \cdot 6 \mathrm{H}_{2} \mathrm{O}$ 一定とした。ホウ酸濃度が低い時, 淡かっ色に着色されたアルミニウム陽極酸化皮膜上に多 量の緑色付着物が認められた。ホウ酸濃度の变化により 分極曲線は複雑な変化を示した。

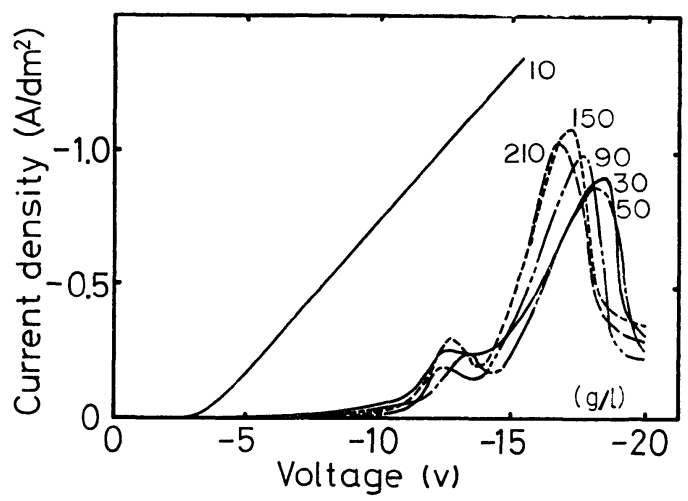

Fig. 6 Cathodic polarization curves of oxide film in $\mathrm{NiSO}_{4}-\mathrm{H}_{3} \mathrm{BO}_{3}$ solution.--Effects of $\mathrm{NiSO}_{4}$ concentration.

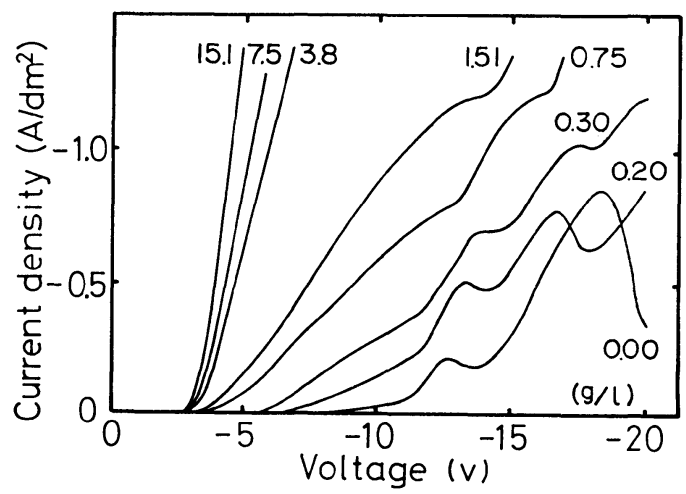

Fig. 7 Cathodic polarization curves of oxide film in $\mathrm{NiSO}_{4}-\mathrm{H}_{3} \mathrm{BO}_{3}$ solution.-Effect of $\left(\mathrm{NH}_{4}\right)_{2} \mathrm{SO}_{4}$ addition. 


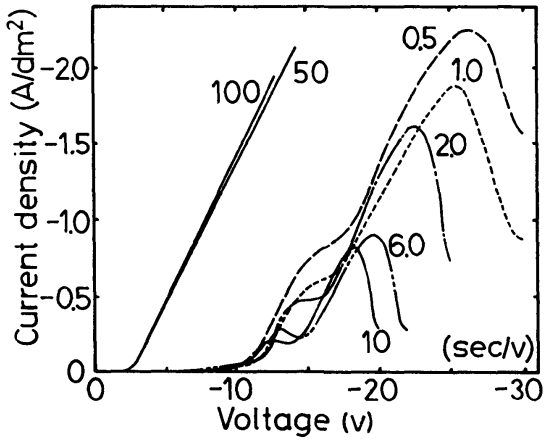

Fig. 8 Cathodic polarization curves of oxide film in $\mathrm{NiSO}_{4}-\mathrm{H}_{3} \mathrm{BO}_{3}$ solution.-Effects of scanning speed.

本報の実験においてはアルミニウム陽極酸化皮膜の厚 さを一定にしたが，陽極酸化皮膜のバリヤ一層が薄い時 は， $-15 \mathrm{~V}$ 以上のカソード過電圧で第 4 電流ピークが現 われてくる5)。この電流ピークは吉田らが指摘している 水の直接還元によるカソード電流(4) と思われる。

\section{4. 結言}

硫酸ニッケルーホウ酸混合水溶液中でアルミニウム陽 極酸化皮膜（硫酸浴化成，皮膜厚さ $9 \mu \mathrm{m}$ ）を電位走查法

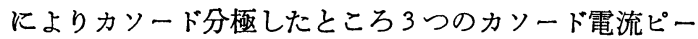
クが観察された。これら電流ピークの帰属を決定するた めに，電解液組成を変化させてカソード分極曲線を測定 した。乞の結果， $-4 \mathrm{~V}$ 付近に現われる電流ピークは $\mathrm{H}^{+}$ イオンの還元電流であり，-13V付近に現われる電流ピ 一クの帰属は不明であった。 $-18 \mathrm{~V}$ 付近の電流ピークは

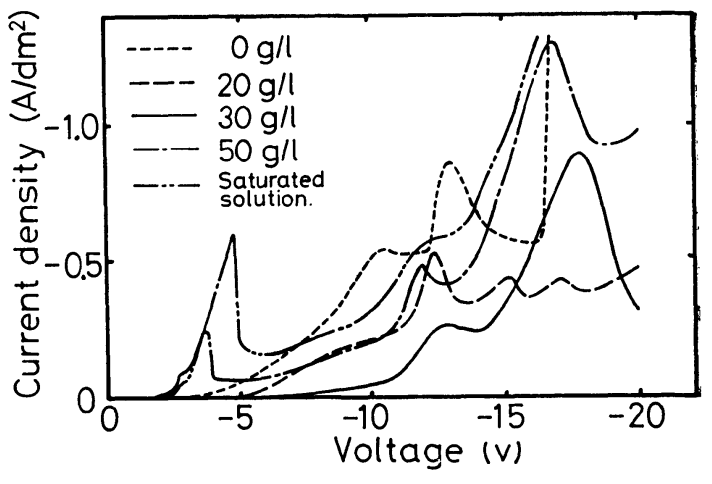

Fig. 9 Cathodic polarization curves of oxide film in $\mathrm{NiSO}_{4}-\mathrm{H}_{3} \mathrm{BO}_{3}$ solution. -Effects of $\mathrm{H}_{3} \mathrm{BO}_{3}$ concentration.

$\mathrm{Ni}^{2+}$ イオンの還元電流であった。

(1978-1-24 受理)

\section{文献}

1）日本特許 公開昭50-67241

2）広兼斉, 月安正, 佐藤朋有；アルミニウムの新しい 表面処理法, 住友化学, 特, 1974一II，32（1974）

3）佐藤敏彦，福島敏郎，馬場宣良；アルミニウム酸化 皮膜上一の金属電析，本誌，29,196（1978）

4) T.Yoshida, I. Matsuda, S. Nomoto, T. Naruse ; Potentiostatic Studies in the Early Sage of Nickel Deposition on Platinum, DENKI KAGAKU, 41, 102 (1973)

5）佐藤敏彦, 酒井茂; 硫酸ニッケル水溶液中でのアル ミニウム陽極酸化皮膜のカソード分極特性に及注す酸 化皮膜厚さの影響，本誌，投稿中 